\title{
Banks with Something to Lose: The Disciplinary Role of Franchise Value
}

R ebecca S. D emsetz, M arc R. Saidenberg, and Philip E. Strahan

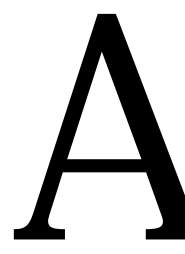

s protectors of the safety and soundness of the banking system, banking supervisors are responsible for keeping banks' risk taking in check. On-site examinations, off-site surveillance, and capital requirements are some of the tools that supervisors use to achieve this goal. Franchise valuethe present value of the stream of profits that a firm is expected to earn as a going concern-makes the supervisor's job easier by reducing banks' incentives to take risk. In banking, sources of franchise value include efficiency, access to markets protected from competition, and valuable lending relationships. Franchise value can help reduce excessive risk taking because banks with high franchise value have much to lose if a risky business strategy leads to insolvency.

Economists studying the relationship between franchise value and risk have noted some interesting patterns over time. Most notably, Keeley (1990) documents declines in bank franchise value during the 1950s, 1960s, and 1970s, when the banking industry was experiencing deregulation and increased competition from nonbank financial institutions. He argues that this drop in franchise value led to increased risk taking in the 1980s, a decade in which the average failure rate for U.S. banks reached a fifty-year high of al most 100 per year.

In this article, we explore the rel ationship between franchise value and risk taking over the 1986-94 period. We extend Keeley's empirical analysis by estimating the effect of franchise value on a variety of measures of bank risk. We find an inverse relationship between franchise value and an "all-in" measure of risk based on stock-return volatility, which incorporates the risks of a bank's asset, liability, and off-balance-sheet positions as well as its leverage. We also use information from the balance sheet to determine how high-franchise-value banks reduce risk. We find that banks with more franchise value hold more capital and have less asset risk than banks with less franchise value. Though their tendency to hold risky loans is similar to that of other banks, banks with high franchise value maintain better diversified loan portfolios. 
FRANCHISE VALUE AND RISK TAKING

IN BANKING

W e define franchise value as the present value of the future profits that a firm is expected to earn as a going concern. Profits are those gains beyond what is required to cover all costs, including the cost of capital. M ost firms in competitive environments cannot generate stable profits because competition tends to force them to lower their prices to levels just high enough to cover all costs. H owever, firms with access to superior technologies, such as new production processes, or scarce factors of production, such as talented managers, may have franchise value.

In banking, franchise value arises from two main sources. First, competition has been limited by regulations, giving banks greater access to profits. We term franchise value stemming from these restrictions "market-related,"

F ranchise value can help reduce excessi ve risk

taking because banks with high franchise value

have much to lose if a risky business strategy

leads to insolvency.

since differences in such franchise value vary across geographic and product markets but not across banks operating in the same geographic and product markets. Although market-related sources of franchise value were important in the 1970s, more recently that importance has diminished. Second, franchise value arises from what we term "bank-related" sources, such as efficiency differences and variations in the value of lending relationships. These bank-related factors continue to be an important source of franchise val ue today.

Market-Related Sources of Fran Chise Value B efore the 1970s, banks faced limits on geographic expansion both within states and across state borders. The D ouglas Amendment to the Bank Holding Company Act of 1956 prevented bank holding companies (BHCs) from acquiring an out-of-state bank unless that bank's state explicitly permitted such acquisitions by statute. Since no state al lowed such acquisitions, hol ding companies were in effect prohibited from operating across state lines. In addition, before 1970, about two-thirds of the states had laws restricting intrastate branching.

Both restrictions effectively limited competition within the banking industry, thereby providing banks with a greater opportunity to build franchise value. This opportunity varied across banking markets. ${ }^{1}$ For instance, banks located in states permitting no branching faced less competition than those located in states allowing limited branching.

Competition among banks changed dramatically from the mid-1970s to the mid-1990s, however, as most of the restrictions on intrastate and interstate banking were lifted. Between 1975 and 1992, two-thirds of the states relaxed restrictions on intrastate branching. During the 1980s and early 1990s, every state but $\mathrm{H}$ awaii entered into a regional or national interstate banking arrangement whereby bank holding companies could operate across state lines by owning banks in more than one state. In September 1994, the R eigle-N eal Interstate Banking and Branching Efficiency Act became law, permitting nationwide interstate banking and, with state approval, interstate branching. These changes have significantly increased competition within the banking industry and consequently lowered franchise value at many banks.

Franchise value has also declined as a result of innovation. Automated teller machines, introduced in the 1970s, increased competition by permitting banks to penetrate local markets without building full-scale branches. In the late 1970s, nonbank financial institutions such as money market mutual funds began offering close substitutes for bank products, further elevating competition and eroding bank franchise value.

Moreover, by the mid-1980s, R egulation Q interest rate ceilings were fully phased out. W hile this development helped banks compete with other financial intermediaries for savings, it increased competition within the banking industry. ${ }^{2}$ 
Bank-Related SOURCES of Fran Chise Value Although regulatory and technological changes have eroded market-related sources of franchise value, bank-related sources remain important. For example, a bank's branch network can give it a competitive advantage in dealing with customers who prefer the convenience of full-service banking at a local branch. In recent years, we have also seen banks use the locational and marketing advantages of branch networks to sell financial products such as mutual funds and life insurance. Moreover, as in all businesses, some banks are simply more efficient than others. The better-managed ones derive franchise val ue from their ability to provide banking services less expensively than their competitors. While the removal of barriers to geographic expansion increased competition and reduced franchise value at many banks, the better-managed banks may have benefited from the opportunity to grow at the expense of their poorly managed rivals ( (ayaratne and Strahan 1996).

Banks' unique relationships with many of their borrowers may also generate franchise value. Banks typically establish long-term relationships that allow them to gain private information on the characteristics and credit risks of their borrowers-information not readily available to other bank or nonbank lenders (Berger and U dell 1995; Petersen and Rajan 1995). These relationships reduce the cost of loan origination, making lending more profitable. Lending relationships continue to be an important source of franchise value.

\section{How Does Fran chise Value Affect}

\section{BANK BEHAVIOR?}

Firms that succeed in building franchise value will seek to preserve it. Consequently, firms with large amounts of franchise val ue may be predisposed to operate more safely than those with little or none. For instance, high-franchise value banks may be more likely to hold capital in excess of that required by regulations, to limit their exposure to highrisk borrowers, and to hold well-diversified loan portfolios. In using derivatives, they may also be more likely to hedge against losses stemming from changes in interest rates and foreign exchange rates than to speculate. These strategies minimize the likelihood that such banks will lose their franchise value through insolvency.

Franchise val ue plays a particularly important role in banking because it helps mitigate the "moral hazard problem" associated with the federal safety net. The safety net, composed of the Federal Reserve's discount window, federal deposit insurance, and extensive supervision and regulation of banks, helps ensure the soundness of the banking system. H owever, this protection does not come without cost. The safety net creates a moral hazard problem by insulating bank creditors from losses, thereby limiting their incentive to restrain risk taking. Insured depositors have little motivation to keep risk in check by demanding interest rates commensurate with bank risk or by withdrawing deposits when banks become riskier. Franchise value can help lessen the moral hazard problem by increasing banks' incentives to operate safely, thereby

B anks' unique relationships with many of their

borrowers may al so generatefranchise value... .

These relationships reduce the cost of Ioan

origination, making lending moreprofitable.

aligning their interests with those of the deposit insurer and bank supervisor. ${ }^{3}$

An example may clarify the point. Consider the incentives facing the imaginary FirstR isk Bank, which has little capital and little or no franchise value. Its owners may decide to make high-risk loans to a high-tech startup, knowing that if the loans are repaid, the bank will earn hefty profits. ${ }^{4}$ If the loans default and the bank finds itself insolvent, the owners will have lost very little. (Insured depositors would have little reason to discipline FirstRisk Bank because the Federal Deposit Insurance Corporation guarantees their deposits.)

Suppose that FirstRisk Bank gets lucky. The hightech start-up with which it has developed a strong lending relationship develops into the industry leader. The firm becomes very profitable, and FirstRisk Bank becomes profit- 
able as a result of the lending relationship it has forged. $\mathrm{N}$ ow FirstR isk Bank has high franchise value, since as a going concern it can expect strong future profits. W ith franchise value to lose, FirstR isk's owners are likely to rethink their aggressive lending strategy. They will probably avoid further risky lending. M oreover, they will have both the incentive and the ability to raise the bank's capital-to-assets ratio, further lowering the likelihood of losing the valuable lending relationship through insolvency.

$\mathrm{N}$ ote that the cost of failure - as well as FirstRisk's incentive to avoid it- is particularly high if FirstRisk's profitable lending relationship cannot be transferred easily to another lending institution. In general, nontransferable franchise val ue increases the cost of bank failures not just to owners but also to borrowers, who may have difficulty

F ranchise value plays a particularly important

role in banking because it helps mitigate the

"moral hazard problem" associated with the federal safety net.

establishing new lending relationships with other banks. To preserve the franchise value of a fail led bank, the Federal Deposit Insurance Corporation typically searches for a buyer willing to assume the bank's assets and liabilities in their entirety through a purchase-and-assumption transaction. ${ }^{5} \mathrm{~W}$ hen lending relationships are longstanding, however, even such a transaction is unlikely to preserve the full franchise value of the failed bank.

\section{Fran Chise Value and Bank Capital}

Franchise value is not the only force mitigating moral hazard in banking. U ninsured creditors have an incentive to monitor risk taking and to demand returns commensurate with bank risk. Bank supervisors also monitor risk taking through on-site examinations and off-site surveillance and discipline risk taking by enforcing certain rules of operation.

Perhaps the most important of these rules of oper- ation are those dictating the maintenance of minimum capital ratios. Should a risky strategy result in insolvency, bank owners would lose their capital along with any franchise value. By requiring banks to meet capital standards, these regulations give bank owners an additional incentive to avoid excessively risky behavior.

W hile a bank's capital position and its franchise value can each discourage risk taking, franchise value may more consistently align the incentives of the bank owner with those of the supervisor. A bank's capital position tends to vary over time in response to changes in loan demand, interest rates, and general economic conditions. In contrast, characteristics that generate franchise value, particularly those related to efficiency, are more stable. For instance, a bank with high franchise value stemming from its ability to operate as a low-cost provider will have access to profits even under poor economic conditions. This bank will have a strong incentive to avoid excessive risk taking throughout the business cycle.

When capital and franchise value are both adversely affected at a large number of institutions, the ramifications can be severe. The thrift crisis of the 1980s provides a good example. Thrift franchise value fell for many of the same reasons that franchise value fell in banking and because the development of secondary markets in mortgage securities reduced thrifts' ability to earn profits from mortgage lending. Moreover, unlike banks, thrifts faced a very large reduction in capital in the late 1970s and early 1980 s because the value of their mortgage portfolios, which dominate thrift balance sheets, fell sharply in response to increased interest rates. Since the thrifts had lost much of their franchise value, owners had little incentive to rebuild their capital positions. Instead, many used fully insured deposits to increase their holdings of highrisk assets such as junk bonds and commercial real estate. This risky behavior led to a large number of thrift failures and ultimately to the taxpayer bailout of the thrift insurance fund.

In contrast, increases in franchise value should lead banks to strengthen their capital positions voluntarily. In our earlier example, we expected FirstRisk Bank to increase its capital-to-assets ratio to reduce insolvency risk 
Chart 1

Risk of Bank Holding Companies with High and Low Franchise $\mathrm{V}$ al ue

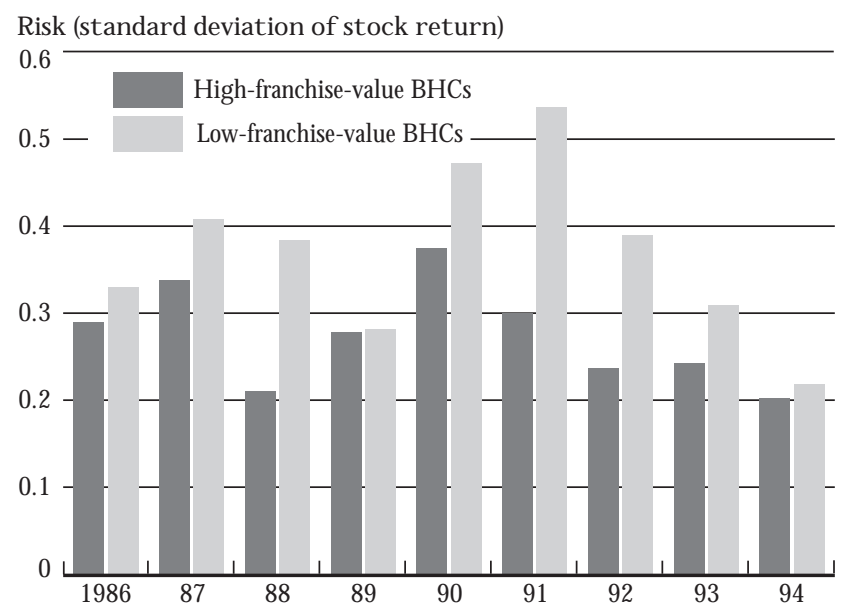

Source: Authors' calculations, based on data from the Center for Research in Security Prices and consolidated financial statements of a sample of publicly traded BHCs.

after franchise value rose. The bank could increase the ratio through stock sales, changes in dividend policies, or changes in the size of the bal ance sheet.

As we have seen, banks with high franchise value have an incentive to reduce risky behavior and strengthen their capital positions. Consequently, we expect risk at banks to be negatively related to franchise value. We look for evidence of this pattern in Chart 1, which reports the average riskiness of bank holding companies with high and low franchise value for 1986-94. We see that lowfranchise-value BHCs are consistently riskier than their high-franchise-value counterparts, except in 1989, when the risk of the two groups is similar. This pattern is consistent with our expectations, but the analysis does not control for other factors that may affect risk.

\section{QUANTIFYING THE FRAN CHISE VALUE/RISK}

\section{RELATIONSHIP}

We now use a series of regressions to confirm that lowfranchise-value BHCs operate with greater risk. ${ }^{6}$ This approach also allows us to quantify the strength of the relationship between franchise value and risk.

Each of our regressions has one of seven measures of risk as its dependent variable. The independent variables include franchise value and two controls: asset size and the growth of personal income in the states where the $\mathrm{BHC}$ operates. ${ }^{7}$ A sset size affects risk in two potentially offsetting ways. On the one hand, larger BH Cs tend to be better diversified and hence less vulnerable to economic shocks. On the other hand, Iarger BH Cs typically engage in riskier activities. For instance, larger B H Cs general ly have a larger share of their loan portfolios in relatively risky commercial and industrial loans and a smaller share in relatively safe mortgage loans. Growth in personal income is included to control for regional business cycles that can affect risk at all banks in a given area. The results of our regressions tell us whether differences in franchise value can explain differences in risk taking among $\mathrm{BHCs}$ of similar size in similar economic environments.

The dependent variables in our seven regressions are measured using natural logarithms. The log specification allows the estimated effect of franchise value on risk to diminish as franchise value grows and risk falls. We believe this approach is appropriate because the threat of insolvency motivates banks to reduce risk and because the likelihood of insolvency is low for banks with sufficiently low levels of risk. These banks have little incentive to reduce risk further as franchise value rises.

We estimate each of our regressions using fixedeffects and random-effects models. Because our data set follows a sample of BH Cs over time, these models can be used to control for time-invariant, BHC-specific factors that may be related to risk taking but are not explicitly included in our regressions. In a random-effects regression, this is done by specifying a certain mathematical structure to the regression residuals. In a fixed-effects regression, all variables are calculated as deviations from their $\mathrm{BHC}$ means, so that regression results are driven by $\mathrm{BHC}$ specific changes in the regression variables over time.

The advantage of the random-effects model is that cross-sectional differences in risk such as those illustrated in Chart 1 are reflected in the regression coefficients. The advantage of the fixed-effects model is that omitted BHCspecific factors related to risk taking are less likely to bias the regression coefficients. Our regressions also include time fixed effects, that is, each regression controls for changes in the average level of risk over the years in the sample period. 
Measuring Franchise Value and RisK

Recall that franchise value is defined as the present value of a firm's future profits- revenues in excess of all costs, including the cost of capital. One way to quantify franchise value is to look at the difference between a firm's market value and its replacement cost, where replacement cost is the expense of rebuilding the firm today:

F ranchise value $(F V)=$ market value - replacement cost.

The difference between market value and replacement cost will be large when franchise value is high, that is, when there are profits associated with the firm as a going concern.

U nfortunately, neither market value nor replacement cost can be measured directly. We approximate the market value of a BHC's assets by adding the market value

One way to quantify franchise value is to look

at the difference between a firm's market value and its replacement cost.

of its equity (shares of stock outstanding times price per share) and the book value of its liabilities. ${ }^{8}$ W hen a BHC purchases an asset for more than its book value, the difference between its book value and the purchase price is accounted for on the purchaser's books as goodwill. Because this difference is a component of the purchaser's franchise value, we approximate the replacement cost of a BH C's assets using the book value of its assets minus goodwill. Finally, we divide franchise value by assets (net of goodwill) to derive a scal efree measure:

$$
\frac{F V}{(A-g o d w i l l)}=\frac{E+L-(A-g o o d w i l l)}{(A-g o o d w i l l)},
$$

where $E$ is the market val ue of equity, $L$ is the book value of liabilities, and $A$ is the book value of assets. Adding 1 and simplifying gives a proxy (Q) for the well-known "Tobin's q":

$$
Q=\frac{E+L}{(A-g 00 d w i T)} .
$$

Following Kedey, we use this ratio to measure franchise value in the empirical analysis that follows. ${ }^{9}$

The $Q$ ratio has the advantage of permitting comparability across $\mathrm{BHCs}$ of different sizes. For instance, if the market value of a BH C's assets (measured by $E+L$ ) is $\$ 520$ million and the replacement cost of those assets (measured by $A$ - goodwill) is $\$ 500$ million, franchise value equals $\$ 20$ million (4 percent of replacement cost) and Q equals 1.04. For a BHC with franchise value of $\$ 20$ million and a replacement cost of $\$ 1$ billion, $Q$ equals 1.02 , since franchise value equals only 2 percent of replacement cost. $\mathrm{N}$ ote that measurement of $\mathrm{Q}$ requires information on the market value of the firm. Franchise value may be difficult to measure for firms without publicly traded stock.

In the first part of our analysis, we use risk mea sures that are al so derived from stock market data. We start by calculating an all-in measure of risk, designed to encompass all of the BHC's risk-taking activities, including the riskiness of its assets and liabilities, its choice of off-bal ance-sheet activities, and its chosen capital-to-assets ratio. Our all-in risk measure is based on the variability of BHC stock returns over time. In particular, we calculate the standard deviation of weekly stock returns for a given $\mathrm{BH} C$ in a given year. Since stock returns reflect changes in the market's perceptions of future profitability, a high standard deviation in the returns indicates that the expected profits of a BHC are fluctuating rapidly - a sign that the $\mathrm{BHC}$ is pursuing risky activities. We discuss additional measures of risk below, including measures that separate the BHC's portfolio risk from its capital-to-assets ratio. Together, portfolio risk and capital determine all-in risk.

\section{DATA DESCRIPTION}

Our analysis is based on a sample of more than $100 \mathrm{BHCS}$ with publicly traded stock. In 1993, they ranged in size from $\$ 170$ million to $\$ 231$ billion in assets and together held a little less than half of all U.S. banking assets. Our data set spans the 1986-94 period. Because most of the institutions in our sample operated in each of the years included in the sample period, we have 938 BHC-year observations. ${ }^{10}$ We obtain the information needed to calculate franchise value and all-in risk from the Center for 
R esearch in Security Prices data tapes and from regulatory reports (Y-9C reports) that contain consolidated financial statements for BHCs. Data used to calculate franchise value are from the beginning of each calendar year in the sample period. This timing helps ensure that any causal relationship runs from franchise value to $\mathrm{BHC}$ risk and not the other way around.

Summary statistics describing franchise value, allin risk, and the other variables used in our analysis appear in Table 1. As the table indicates, considerable variability in risk taking exists among the BHCs in our sample. The annualized standard deviation of weekly stock returns averages 33 percent in our sample, but ranges from around 10 percent to slightly more than 180 percent. We describe several additional measures of risk below.

O ur measure of franchise value averages just over 1.00 , at 1.02. On average, the market value of assets for the BHCs in our sample exceeds the book value of assets by 2 percent. $^{11}$ The standard deviation of 0.03 reveals some dispersion in franchise values, but most of the BHCs in our sample have franchise values near the average. $\mathrm{H}$ owever, the minimum and maximum statistics tell us that the franchise value distribution is somewhat skewed. BHCs with franchise values below 1.00 tend to bunch up near the average; however, one BH C's market value of assets is more than 20 percent larger than its book value of assets.

\section{Does Fran Chise Value N egatively \\ AFFECT RISK?}

The results of our first regression, in which all-in risk is regressed on franchise value, $\mathrm{BHC}$ size, and personal income growth, confirm that $\mathrm{BH} C$ s with the highest franchise value exhibit the lowest all-in risk (Table 2). The coefficient associated with franchise value is negative in

The results of our first regression . . . confirm

that B HCs with the highest franchise value exhibit the lowest all-in risk.

both the random-effects and fixed-effects models. Moreover, the coefficient associated with franchise value is statistically significant, that is, we can be confident that franchise val ue is negatively related to all-in risk. ${ }^{12}$

Our estimates indicate that the effects of franchise value on risk are not just statistically reliable but al so eco-

Table 1

BAN K HOLDIN G COMPANY SUMMARY STATISTICS

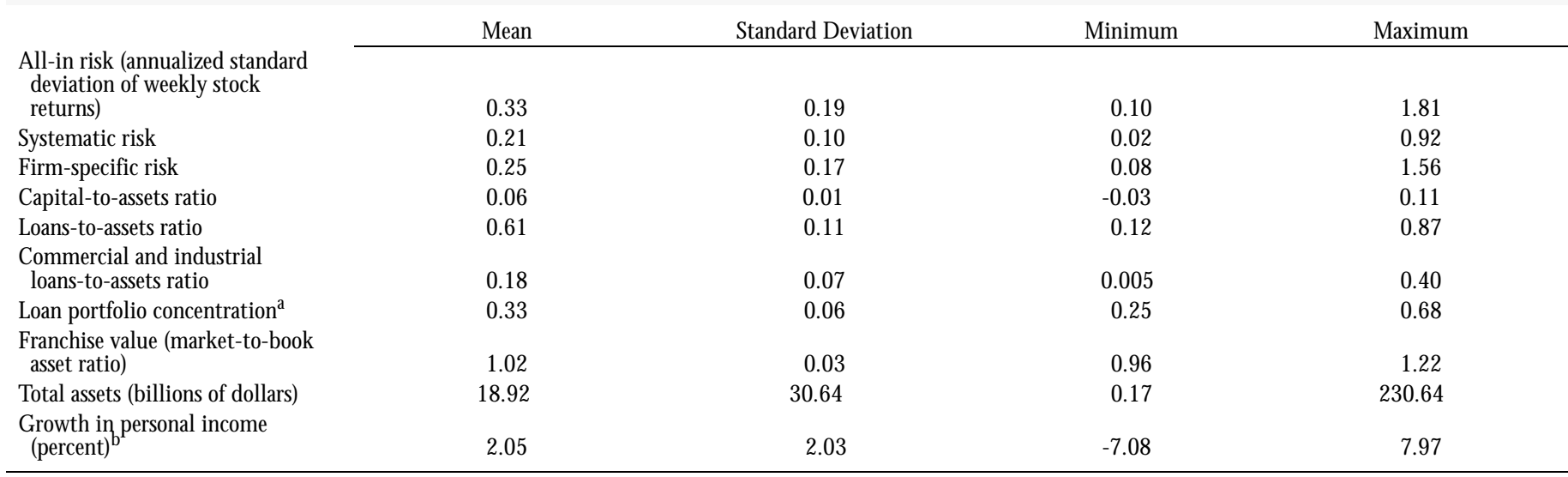

Source: Authors' calculations, based on data from the Center for R esearch in Security Prices and consolidated financial statements of a sample of publicly traded BH Cs. N otes: Pooled data are from 1986 to 1994 . There are a total of 938 observations.

${ }^{a}$ Loan portfolio concentration equals the sum of the squared shares of each loan category (real estate, consumer, commercial and industrial, and other).

${ }^{\mathrm{b}} \mathrm{G}$ rowth in personal income for each $\mathrm{BHC}$ is computed as the asset-weighted average of the growth in real personal income for each state in which the BH C has one or more commercial bank subsidiaries. 
nomically meaningful. A 1 percentage point increase in franchise value leads to a decrease in all-in risk of about 3.6 percent. This means that, on average, all-in risk at a BHC with high franchise value (equal, for example, to 5 percent of assets) would be about 18 percent lower than at a similar $\mathrm{BHC}$ with no franchise value.

Both asset size and personal income growth are negatively related to all-in risk, though only the coefficient on personal income growth in the random-effects specification is statistically significant. Strong economic conditions reduce variability in the stock returns of the BHCs in our sample when we control for the other variables in the regression.

\section{FRAN CHISE VALUE AND THE MIX OF BHC RISKS} We now introduce two new measures of $\mathrm{BHC}$ risk (Table 3 ). They are derived by splitting our all-in risk measure into two components: systematic risk, which reflects risks stemming from underlying economic factors that affect the

Table2

RELATIONSHIP BETWEEN ALL-IN RISK

AND FRANCHISE VALUE

\begin{tabular}{lcc} 
& \multicolumn{2}{c}{ All-In Risk } \\
\cline { 2 - 3 } Franchise value & $-3.566^{* *}$ & \\
\cline { 2 - 3 } & $(0.453)$ & $(0.501)$ \\
Size & -0.025 & -0.063 \\
& $(0.016)$ & $(0.046)$ \\
Growth in personal & & \\
income & $-0.020^{\mathrm{a}}$ & -0.010 \\
& $(0.007)$ & $(0.007)$ \\
R-squared & 0.328 & $0.402^{\mathrm{b}}$ \\
\hline
\end{tabular}

Source: Authors' calculations, based on data from the Center for R esearch in Security Prices and consolidated financial statements of a sample of publicly traded BHCs.

$N$ otes: Table presents the coefficients from regressions of the log of all-in risk (annualized standard deviation of weekly stock returns) on franchise val ue (market-to-book asset ratio), size (log of total assets), and growth in personal income. Regressions include time fixed effects (not shown). Standard errors are in parentheses. Pooled data are from 1986 to 1994 . There are a total of 938 observations.

${ }^{\text {a }} \mathrm{G}$ rowth in personal income for each $\mathrm{BHC}$ is computed as the asset-weighted average of the growth in real personal income for each state in which the BHC has one or more commercial bank subsidiaries.

${ }^{b}$ The reported $\mathrm{R}$-squared in the fixed-effects model corresponds to a regression in which all variables are calculated as deviations from their $\mathrm{BHC}$ means.

* Statistically significant at the 5 percent level.

** Statistically significant at the 1 percent level. banking industry as a whole (such as interest rate risk), and firm-specific risk, which reflects risks unique to particular banks (such as the industry mix of loans in a commercial and industrial loan portfolio). Systematic risk is derived by measuring the extent to which each BHC's stock return tracks those of a large sample of BH Cs. Firm-specific risk is derived from the difference between all-in risk and systematic risk. ${ }^{13}$

Our earlier discussion suggests that BH Cs would like to reduce risks across the board as franchise value rises. But it may be harder for BH Cs to reduce certain kinds of risks than others. For instance, a BHC that specializes in lending to a particular industry may find it difficult to diversify into new industries. As a result, the firm-specific component of all-in risk may be less sensitive to changes in franchise value than the systematic component.

A second line of reasoning suggests that systematic

Table 3

RELATIONSHIP BETWEEN RISK COMPONENTS

AND FRANCHISE VALUE

\begin{tabular}{|c|c|c|c|c|}
\hline & \multicolumn{2}{|c|}{ Systematic Risk } & \multicolumn{2}{|c|}{ Firm-Specific Risk } \\
\hline & $\begin{array}{c}\text { Random- } \\
\text { Effects M odel }\end{array}$ & $\begin{array}{l}\text { Fixed-Effects } \\
\text { M odel }\end{array}$ & $\begin{array}{c}\text { Random- } \\
\text { Effects M odel }\end{array}$ & $\begin{array}{c}\text { Fixed-Effects } \\
\text { M odel }\end{array}$ \\
\hline $\begin{array}{l}\text { Franchise } \\
\text { value }\end{array}$ & $\begin{array}{c}-3.676^{* *} \\
(0.501)\end{array}$ & $\begin{array}{l}-3.061 * * \\
(0.580)\end{array}$ & $\begin{array}{l}-3.445^{* *} \\
(0.506)\end{array}$ & $\begin{array}{l}-2.721^{* *} \\
(0.568)\end{array}$ \\
\hline Size & $\begin{array}{c}0.070 * * \\
(0.016)\end{array}$ & $\begin{array}{l}-0.036 \\
(0.054)\end{array}$ & $\begin{array}{l}-0.081^{* *} \\
(0.017)\end{array}$ & $\begin{array}{l}-0.074 \\
(0.053)\end{array}$ \\
\hline $\begin{array}{l}\text { Growth in } \\
\text { personal } \\
\text { income }\end{array}$ & $\begin{array}{l}-0.011 \\
(0.008)\end{array}$ & $\begin{array}{c}-0.0001 \\
(0.009)\end{array}$ & $\begin{array}{l}-0.032 * * \\
(0.008)\end{array}$ & $\begin{array}{l}-0.021^{*} \\
(0.008)\end{array}$ \\
\hline R-squared & 0.417 & $0.473^{b}$ & 0.290 & $0.283^{b}$ \\
\hline
\end{tabular}

Source: Authors' cal culations, based on data from the Center for R esearch in Security Prices and consolidated financial statements of a sample of publicly traded BH Cs.

$N$ otes: Table presents the coefficients from regressions of the logs of systematic risk and firm-specific risk on franchise value (market-to-book asset ratio), size (log of total assets), and growth in personal income. Regressions include time fixed effects (not shown). Standard errors are in parentheses. Pool ed data are from 1986 to 1994. There are a total of 938 observations.

${ }^{a} \mathrm{G}$ rowth in personal income for each $\mathrm{BHC}$ is computed as the asset-weighted average of the growth in real personal income for each state in which the $\mathrm{BH} C$ has one or more commercial bank subsidiaries.

${ }^{b}$ The reported $\mathrm{R}$-squared in the fixed-effects models corresponds to a regression in which all variables are calculated as deviations from their BH C means.

* Statistically significant at the 5 percent level.

** Statistically significant at the 1 percent level. 
risk may be less sensitive to changes in franchise value. Franchise value should mitigate risk taking because $\mathrm{BHC}$ owners fear that they will lose the value of their franchise through insolvency. H owever, if a BH C faces severe financial difficulties at the same time as many other $\mathrm{BHCS}$, it may be more likely to receive assistance from the government, since one of the primary goals of the federal safety net is to stabilize the financial system during times of crisis. Consequently, BHCs may have little incentive to lower systematic risk, even when franchise value is high.

Empirically, we find that franchise value has a similar negative effect on systematic and firm-specific risk (Table 3). A 1 percentage point increase in franchise value leads to a decline of roughly 3 percent in firm-specific and systematic risk. Perhaps BH Cs can adjust these two types of risk with similar ease. Alternatively, any difficulties associated with reducing firm-specific risk may simply be counterbal anced by weaker incentives to reduce systematic risk.

The relationship between personal income growth and $\mathrm{BHC}$ risk, particularly in the firm-specific risk regression, also proves to be negative (Table 3). Asset size, which was insignificant in Table 2, is negatively related to firm-

Chart 2

Bank Holding Company Risk and Franchise Val ue

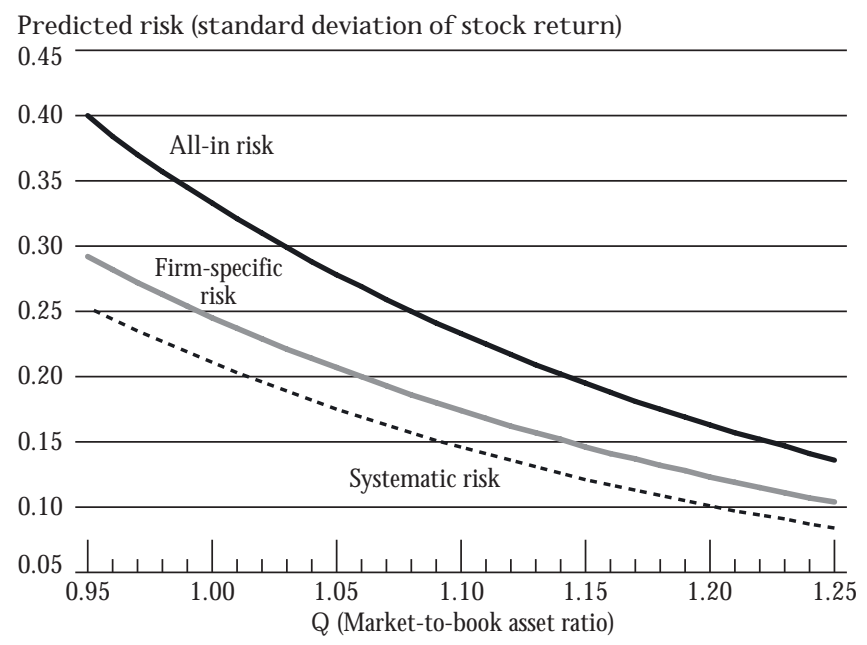

Source: Authors' cal culations, based on data from the Center for Research in Security Prices and consolidated financial statements of a sample of publicly traded BHCs.

$N$ ote: The underlying cal culations are based on coefficients from the randomeffects models and sample means for the log of total assets (15.96) and growth in personal income (2.05). specific risk but positively related to systematic risk in the random-effects model. This apparent inconsistency can be reconciled by noting that larger BH Cs are generally better diversified than smaller ones but have lower capital-toassets ratios and engage more intensively in certain risky activities. The negative influence of size in the firm-specific risk regression reflects the better diversification of larger $\mathrm{BH}$ Cs. The positive influence of size in the systematic risk regression reflects differences in the mix of activities pursued by small and large BHCs. The two effects are approximately offsetting, leaving little relationship between $\mathrm{BH} C$ size and all-in risk. ${ }^{14}$

Overall, our empirical tests strongly support the hypothesized negative relationship between franchise value and risk. Analyses using measures of risk derived from BHCs' stock returns suggest that BHCs with strong profit potential, and hence with much to lose in the event of insolvency, display lower systematic risk, lower firm-specific risk, and lower overall risk. Using results reported in Tables 2 and 3, we plot the predicted level of risk against franchise value for a typical BHC in Chart 2. All thre marketbased measures of $\mathrm{BH}$ C risk fall as franchise value rises.

\section{How Do High-Fran Chise-Value Banks}

\section{REDUCE RISK?}

Recall our example of FirstRisk Bank, which seeks to reduce its insolvency risk as its franchise value rises. FirstR isk can do so in a variety of ways. It can boost its capital-to-assets ratio by retaining earnings or issuing new equity, or it can reduce portfolio risk by steering clear of risky loans or further diversifying its loan portfolio. We now determine which type of behavior-strengthening capital, reducing portfolio risk, or both- underlies the relationship between franchise val ue and risk for the BHCs in our sample.

We use two approaches to explore this issue. First, we estimate regressions using the capital-to-assets ratio and three measures of portfolio risk derived from the balance sheet as dependent variables. Independent variables are the same as those used above (franchise value, BHC size, and state-level personal income growth). The results suggest that high-franchise-value BHCs have lower all-in risk because they have stronger capital positions and safer 
portfolios. H owever, since no all-encompassing measure of portfolio risk is available from the balance sheet, this approach does not allow us to quantify the effect of franchise value on overall portfolio risk.

In our second approach, we go back to using stockreturn variability to measure risk, but we include the logarithm of the capital-to-assets ratio as an additional independent variable. This approach allows us to control for the

[ Our] results suggest that high-franchise value

B H C s have low er all-in risk because they have

stronger capital positions and safer portfolios.

effect of leverage on stock-return variability when estimating the effect of franchise value. Because capital (like portfolio risk) is chosen by the $\mathrm{BHC}$, we are more comfortable estimating a regression with capital as a dependent variable (as in our first approach). N evertheless, adding capital to the right-hand side of regressions with all-in risk, systematic risk, or firm-specific risk as dependent variables helps us determine whether franchise value has an effect on risk taking above and beyond its effect on capital. In other words, these regressions enable us to obtain an estimate of the effect of franchise value on overall portfolio risk. ${ }^{15}$

The results of our first approach are reported in Table 4. We look for evidence that high-franchise-value $\mathrm{BH}$ Cs reduce risk by: (1) increasing their capital-to-assets ratios, (2) shifting from loans in general to safer assets, (3) shifting from relatively high-risk commercial and industrial loans to less risky loans and other assets, and (4) decreasing loan portfolio concentration. We measure loan portfolio concentration by squaring and summing the shares of the loan portfolio in each of four loan groups: commercial and industrial, real estate, consumer, and other loans. The resulting concentration index ranges from zero to one, taking on higher values for portfolios concentrated in one or two of these four loan groups. Information on loans, assets, and capital was obtained from BHCs' Y-9C reports. ${ }^{16}$

Table 4

RELATION SHIP BETWEEN BALAN CE-ShEet RISK AND FRAN ChISE VALUE

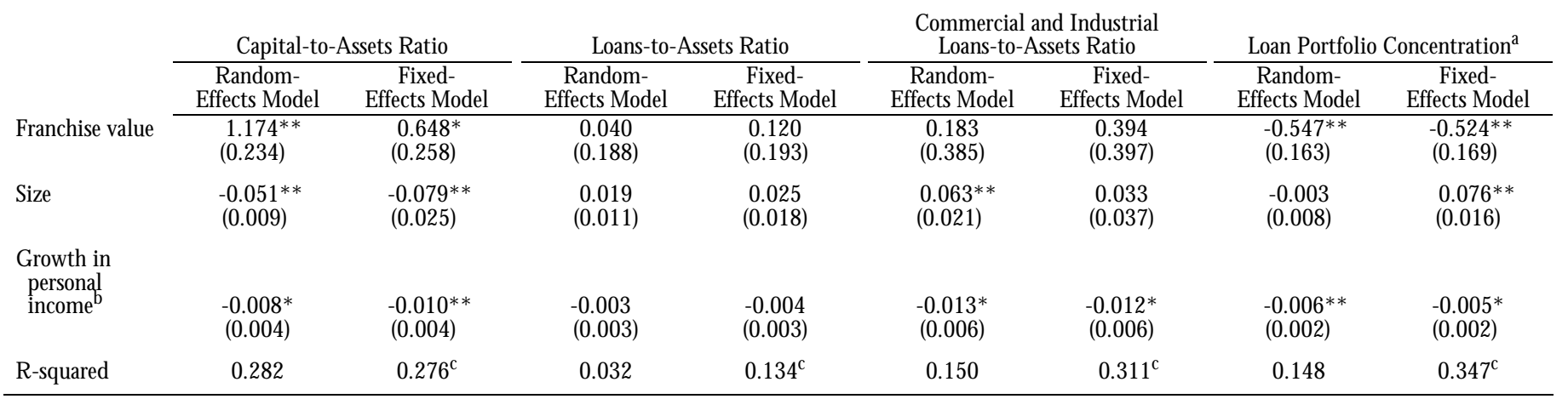

Source: Authors' cal culations, based on data from the Center for R esearch in Security Prices and consolidated financial statements of a sample of publicly traded BH Cs.

$N$ otes: Table presents the coefficients from regressions of the logs of the capital-to-assets ratio, the loans-to-assets ratio, the commercial and industrial loans-to-assets ratio, and loan portfolio concentration on franchise value (market-to-book asset ratio), size (log of total assets), and growth in personal income. Regressions include time fixed effects (not shown). Standard errors are in parentheses. Pooled data are from 1986 to 1994 . There are a total of 938 observations. Regressions including the capital-toassets ratio have 936 observations because capital is negative for two observations.

${ }^{a}$ Loan portfolio concentration equals the sum of the squared shares of each loan category (real estate, consumer, commercial and industrial, and other).

${ }^{\mathrm{b}} \mathrm{G}$ rowth in personal income for each $\mathrm{BHC}$ is computed as the asset-weighted average of the growth in real personal income for each state in which the BH C has one or more commercial bank subsidiaries.

${ }^{\mathrm{C}}$ The reported $\mathrm{R}$-squared in the fixed-effects models corresponds to a regression in which all variables are cal culated as deviations from their BH C means.

* Statistically significant at the 5 percent level.

** Statistically significant at the 1 percent level. 
We find strong evidence that BHCs with high franchise value reduce risk by increasing their capital-toassets ratios and by decreasing loan portfolio concentration. The franchise value coefficient in the capital regression is positive and highly significant, and the coefficient in the Ioan portfolio concentration regression is negative and highly significant. In contrast, we find no evidence that high-franchise-value BH Cs shift from lending in general or from commercial and industrial lending in particular to safer assets, suggesting that it is costly for BH Cs to adjust their lending behavior in response to changes in franchise value. It is possible, however, that the regression coefficients underestimate the effect of franchise value on lending. Since franchise value stems in part from lending relationships, BHCs that devote a greater share of their assets to lending may have higher franchise value, all else equal. This effect may counteract any negative influence of franchise value on the loans-to-assets ratio.

The results of our second approach are reported in Table 5. All-in risk, systematic risk, and firm-specific risk are each regressed on franchise value, BHC size, personal income growth, and the logarithm of the capital-to-assets ratio, included to control for the effect of leverage. The franchise value coefficients in Table 5 are smaller than those in Tables 2 and 3, but in all three regressions we continue to find a negative and significant coefficient on franchise value. Together, Tables 4 and 5 show that BH Cs with higher franchise value have lower risk because they have stronger capital positions and safer portfolios.

\section{CONCLUSION}

We have argued that franchise value hel ps offset the incentive for firms to increase risk because firms with the ability to generate profits will act to protect their valuable franchise. The discipline introduced by franchise value is particularly important in the banking industry, where the federal safety net insulates banks from costs normally borne by risky firms.

Our empirical results support the theory that banks that are more efficient, are located in less competitive markets, or have valuable lending relationships operate more safely. We find that high-franchise-value banks hold more capital and take on less portfolio risk, leading to lower levels of overall risk. We al so observe a negative rela

Table5

Relationship between Risk and Franchise Value Controlling for Capital

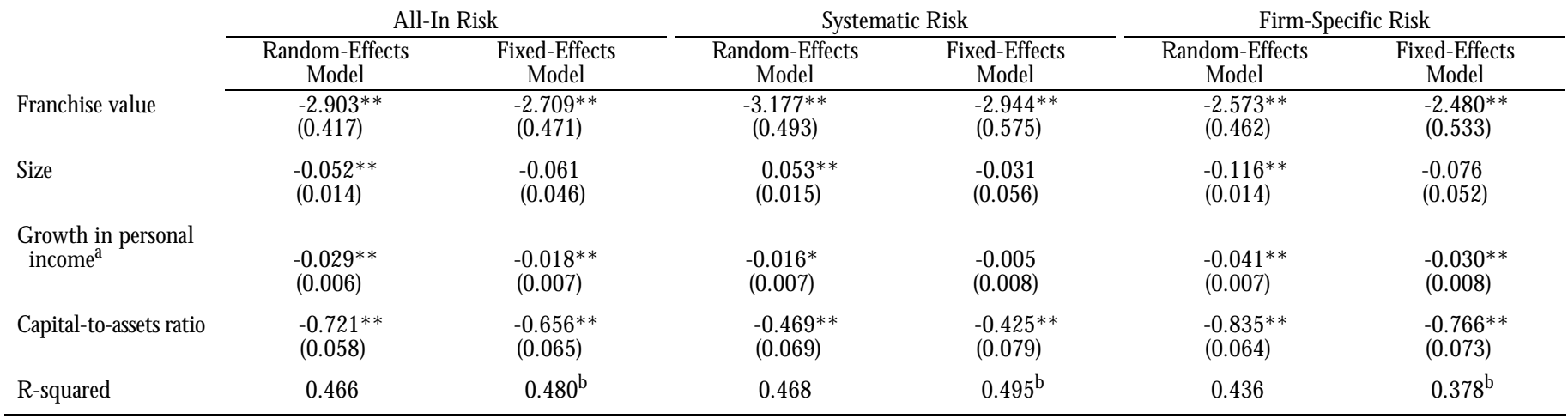

Source: Authors' cal culations, based on data from the Center for R esearch in Security Prices and consolidated financial statements of a sample of publicly traded BH Cs.

$\mathrm{N}$ otes: Table presents the coefficients from regressions of the logs of all-in risk, systematic risk, and firm-specific risk on franchise value (market-to-book asset ratio), size ( $\log$ of total assets), growth in personal income, and log of the capital-to-assets ratio. Regressions include time fixed effects (not shown). Standard errors are in parentheses. Pooled data are from 1986 to 1994. There are a total of 936 observations.

${ }^{a} \mathrm{G}$ rowth in personal income for each BHC is computed as the asset-weighted average of the growth in real personal income for each state in which the BH C has one or more commercial bank subsidiaries.

${ }^{b}$ The reported $\mathrm{R}$-squared in the fixed-effects models corresponds to a regression in which all variables are cal culated as deviations from their $\mathrm{BH}$ C means.

* Statistically significant at the 5 percent level.

** Statistically significant at the 1 percent level. 
tionship between franchise value and systematic risk (the risk related to factors that affect the banking industry as a whole) and between franchise value and firm-specific risk (the risk unique to individual institutions).

Our results do not suggest a specific supervisory approach; however, they highlight the importance of continued monitoring of franchise value in the banking industry. W hen franchise value is high, banks are less inclined to take excessive risk, reducing the potential for conflicts between banks and their supervisors. This behavior holds even during periods of economic distress, when capital may be low. In contrast, the interests of banks may conflict with those of supervisors when franchise value is low, especially during periods of economic distress. As the thrift crisis of the 1980s demonstrated, institutions with low capital and low franchise value may have a strong incentive to increase risk and "go for broke." 


\section{ENDNOTES}

1. Some analysts apply the term "charter val ue" to these market-related sources of franchise value in banking. The term reflects the fact that investors would be willing to pay a significant amount for the right to open a bank in markets protected from competition.

2. See Edwards and Mishkin (1995) for a more complete discussion of changes in banking since the mid-1970s.

3. M arcus (1984), K eel ey (1990), and A charya (1996) show formally how franchise value can mitigate moral hazard problems in banking.

4. W e do not consider agency problems that may cause the incentives of managers and owners to diverge. Demsetz, Saidenberg, and Strahan (1996) show that the effect of franchise value on risk remains important even after controlling for managers' ownership share.

5. Acharya (1996) shows that closing an insolvent bank with large amounts of franchise value can be less than optimal since much of its franchise value would be lost.

6. Our regressions are similar in structure to those estimated by Kelley, though our measures of $\mathrm{BHC}$ risk differ from those that $\mathrm{K}$ eel ey analyzes, and he works with data from an earlier period. $\mathrm{H}$ e uses two measures of risk: the interest rate paid on large certificates of deposit and the marketval ue capital-to-assets ratio. Keel ey also estimates a somewhat more complicated system of equations than the one estimated here.

7. Since many of the BHCs in our sample operate in more than one state, we measure growth in personal income using the asset-weighted average of real personal income growth across states in which a BHC has one or more commercial bank subsidiaries.

8. Since we do not observe the market value of liabilities, our measure of franchise value will include the subsidy associated with deposit insurance, which increases with risk taking. Since we seek evidence of an inverse relationship between franchise value and risk taking, this complication makes it more difficult for us to find empirical support for the hypothesis we test.

9. An alternative measure of franchise value is the market-to-book equity ratio, which is highly correlated with the market-to-book asset ratio used here. Our empirical results are not sensitive to the use of this alternative measure of franchise value.

10. The BH Cs in our data set were identified using the Bank Compustat data base. W e worked with only those $\mathrm{BH}$ Cs for which we could retrieve both stock-return data and data from regul atory reports and whose stock traded for at least thirty weeks in a given calendar year. BH Cs acquired in the middle of our sample period were dropped from the sample after the date of acquisition. BHCs that acquired other firms during the sample period remained in the sample. The results presented below are qualitatively similar when we limit our analysis to BH Cs that operated throughout the 1986-94 period.

11. The average value of 1.02 is statistical ly significantly different from 1.00 .

12. Studies show that banks in protected markets operate more safely (Rhoades and Rutz 1982) and less efficiently (Berger and $H$ annan 1994). Initially, this behavior may induce a negative relationship between franchise value and risk since diminished competition can enhance franchise value. Over time, however, inefficient behavior will lead franchise value to decline. W etried controlling for market concentration when empirically examining the relationship between franchise value and risk and found that market concentration could not explain the negative franchise value/risk relationship that we observe.

13. We estimate a five factor return-generating model using factor analysis, which solves for the five vectors and weights that best explain the component of returns common to the BHCs in our sample. Systematic risk is the square root of the portion of total return variance that can be explained by thesefive factors. Firm-specific risk is the square root of the difference between total return variance and the square of systematic risk. See Demsetz and Strahan (1995) for additional detail s on the construction of firm-specific and systematic risk in this sample.

14. See Demsetz and Strahan (forthcoming) for further analysis of the relationship between diversification, size, and risk at BH Cs.

15. A nother way to measure the relationship between franchise value and portfolio risk is to remove the effect of leverage from stock-return variability and use the resulting "deleveraged" risk measure as a dependent variable. We tried making this adjustment by multiplying all-in risk, systematic risk, and firm-specific risk by the capital-to-assets ratio and taking the log of each product. Using the resulting risk measures as dependent variables, we continued to find negative and significant coefficients on franchise value, suggesting a negative relationship between franchise value and portfolio risk. In fact, these coefficients were similar in magnitude to those reported in Table 5.

16. Loans, assets, and capital are measured at the same point in time as franchise value. 


\section{REFERENCES}

A charya, Sankarshan. 1996. "Charter Value, Minimum Capital Requirement and Deposit Insurance Pricing in Equilibrium." JOURNAL OF BAN KING AND FINANCE 20: 351-75.

B erger, A llen, and T imothy $H$ annan. 1994. "The Efficiency Cost of M arket Power in the Banking Industry: A Test of the Quiet Life and Related Hypotheses." Board of Governors of the Federal Reserve System Finance and Economics Discussion Series, no. 94-36.

B erger, A llen, and G regory U dell. 1995. "Relationship Lending and Lines of Credit in Small Firm Finance." J OURNAL OF BUSINESS 68, no. 3: 351-82.

D emsetz, Rebecca S., M arc R. Saidenberg, and Philip E. Strahan. 1996. "Franchise Value, Ownership Structure, and Risk-taking at Banks: The Role of N onregulatory Forces." Federal R eserveBank of N ew Y ork, unpublished paper.

D emsetz, R ebecca S., and Philip E. Strahan. 1995. "H istorical Patterns and Recent Changes in the R elationship between Bank H olding Company Sizeand Risk." Federal ReserveBank of N ew Y ork ECON OMIC PoLICY REVIEW 1, no. 2: 13-26.

- - - Forthcoming. "Diversification, Size, and Risk at Bank H olding Companies." Journal of MONEY, CRedit ANd BANKIn G.
Edwards, Franklin, and Frederic S. M ishkin. 1995. "The Decline of Traditional Banking: Implications for Financial Stability and Regulatory Policy." Federal Reserve Bank of N ew Y ork ECON OMIC POLICY REVIEW 1, no. 2: 27-45.

J ayaratne, Jith, and Philip E. Strahan. 1996. "Entry Restrictions, Industry Evolution and Dynamic Efficiency: Evidence from Commercial Banking." Federal R eserveBank of N ew Y ork Research Paper no. 9630.

Kedey, M ichad. 1990. "Deposit Insurance, Risk, and Market Power in Banking." American ECONOMIC Review 80, no. 5: 1183-200.

M arcus, A lan. 1984. "Deregulation and Bank Financial Policy." J OURn AL OF BANKING AND FINANCE 8: 557-65.

Petersen, M itchell, and Raghuran Rajan. 1995. "The Benefits of Lending Relationships: Evidence from Small Business Data." JoURnAL OF FINANCE 49, no. 1: 3-37.

Rhoades, Stephen A ., and Roger D. Rutz. 1982. "M arket Power and Firm Risk: A Test of the 'Quiet Life' H ypothesis." J OURN AL OF M ONETARY ECONOMICS 9: 73-85.

The views expressed in this article are those of the authors and do not necessarily reflect the position of the Federal Reserve Bank of New York or the Federal Reserve System. The Federal Reserve Bank of New York provides no warranty, express or implied, as to the accuracy, timeliness, completeness, merchantability, or fitness for any particular purpose of any information contained in documents produced and provided by the Federal Reserve Bank of New York in any form or manner whatsoever. 